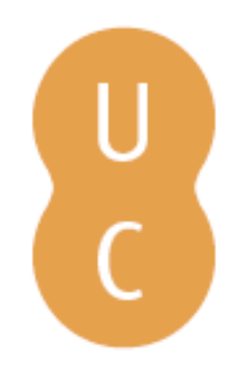

\title{
nombalina
}

\section{O "Nunca ouvido canto" de Camões e as estâncias finais d'Os Lusíadas}

Autor(es): $\quad$ Bernardes, José Augusto Cardoso

Publicado por: Imprensa da Universidade de Coimbra

URL

persistente: $\quad$ URI:http://hdl.handle.net/10316.2/31267

DOI: $\quad$ DOl:http://dx.doi.org/10.14195/978-989-26-0569-2_4585-596

Accessed : $\quad$ 26-Apr-2023 16:11:06

A navegação consulta e descarregamento dos títulos inseridos nas Bibliotecas Digitais UC Digitalis, UC Pombalina e UC Impactum, pressupõem a aceitação plena e sem reservas dos Termos e Condições de Uso destas Bibliotecas Digitais, disponíveis em https://digitalis.uc.pt/pt-pt/termos.

Conforme exposto nos referidos Termos e Condições de Uso, o descarregamento de títulos de acesso restrito requer uma licença válida de autorização devendo o utilizador aceder ao(s) documento(s) a partir de um endereço de IP da instituição detentora da supramencionada licença.

Ao utilizador é apenas permitido o descarregamento para uso pessoal, pelo que o emprego do(s) título(s) descarregado(s) para outro fim, designadamente comercial, carece de autorização do respetivo autor ou editor da obra.

Na medida em que todas as obras da UC Digitalis se encontram protegidas pelo Código do Direito de Autor e Direitos Conexos e demais legislação aplicável, toda a cópia, parcial ou total, deste documento, nos casos em que é legalmente admitida, deverá conter ou fazer-se acompanhar por este aviso.

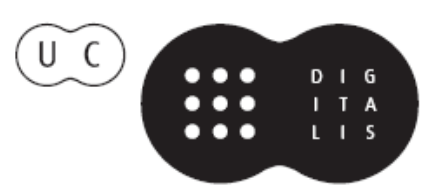




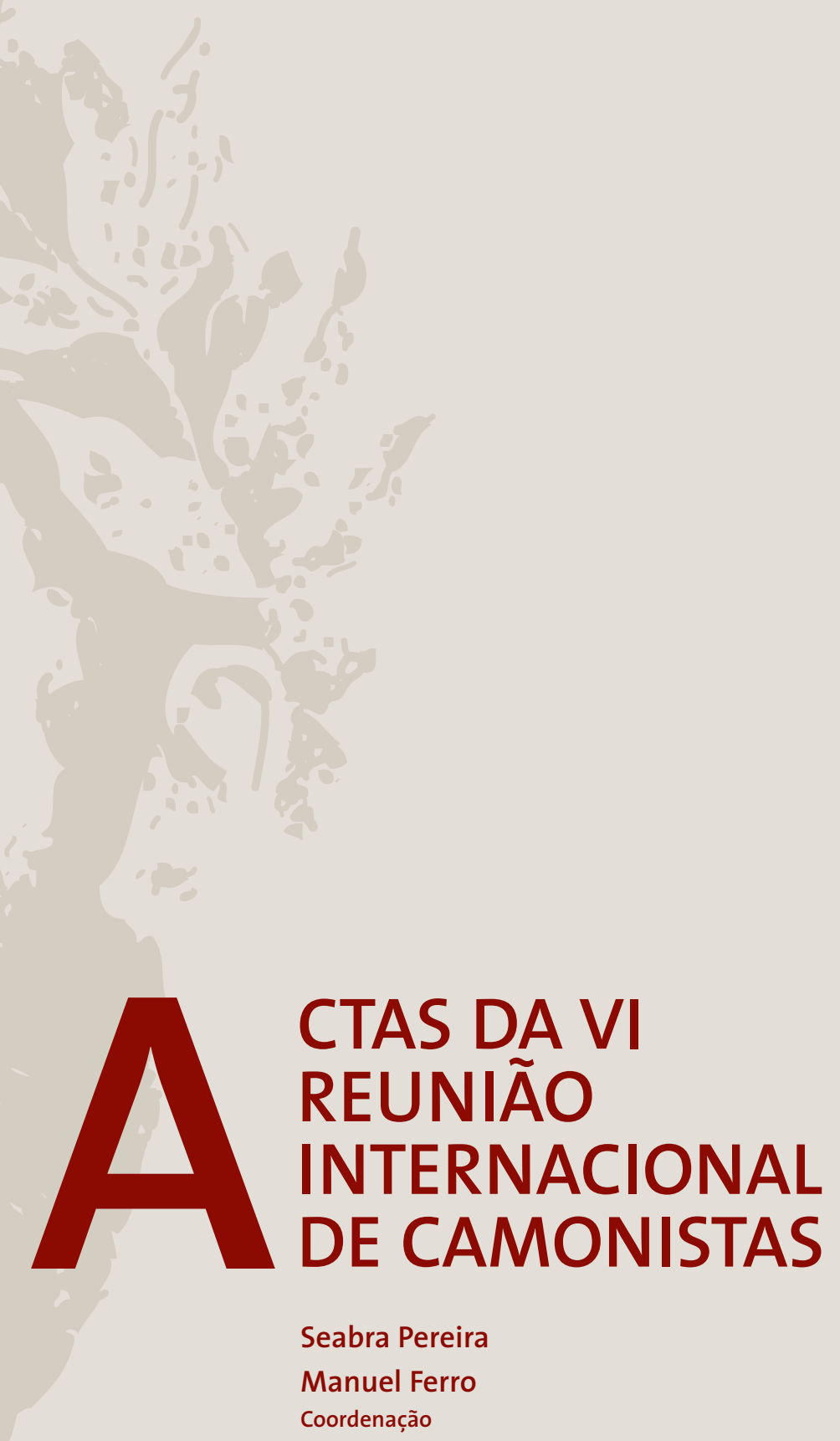


José Augusto Cardoso Bernardes

Universidade de Coimbra

\section{O "NUNCA OUVIDO CANTO" DE CAMÓES E AS ESTÂNCIAS FINAIS D' OS LUSÍADAS}

Objecto de leituras predominantemente parcelares, Os Lusíadas têm sido entendidos ao longo dos tempos como um mosaico de episódios de matizes muito diferentes quando náo contraditórios entre si. O próprio jogo enunciativo que suporta a diegese do poema favorece a seccionação da matéria narrada quer de acordo com os diferentes níveis em que se estratifica (viagem à Índia, intriga mitológica e história de Portugal), quer segundo as coordenadas temático-estilísticas que a balizam: episódios trágicos e líricos como o de Inês de Castro ou o do Adamastor, épico-cavaleirescos como o dos Doze de Inglaterra, hagiográficos como o de S. Tomé, cómico-picarescos como o de Fernão Veloso ou mesmo anti-épicos como o do Velho do Restelo parecem coexistir mais num plano de diversidade e de complementaridade do que num registo de coerência orgânica.

Esta tendência parcelarizante pode naturalmente ser contrabalançada com leituras co-textualizantes dos fragmentos estudados. Mesmo assim, porém, há estâncias que, porque não integram episódios demarcados, têm andado praticamente esquecidas, se exceptuarmos o trabalho de anotação desenvolvido, de forma mais ou menos criteriosa, desde Faria e Sousa até aos nossos dias.

E nem mesmo a circunstância de algumas dessas estâncias se situarem em pontos estratégicos tem obviado a esta situaçáo de menor cuidado. É o que sucede concretamente com as que encerram o poema. Porque já não integram o episódio da ilha dos Amores e também porque se situam num nível exterior à acção épica, as treze estâncias terminais (e em particular as últimas onze) são tidas muitas vezes como mais um excurso exortativo do poeta ao jovem rei, que as circunstâncias históricas, aliás, parecem explicar de forma imediata. E pouco mais se tem aduzido a respeito desses derradeiros acordes do canto camoniano, como se o sentido do poema (o sentido global da acção épica, entenda-se) pudesse passar sem elas.

Através da análise integrada destas estâncias pretendo agora examinar a conjugação de planos que nelas se reflecte. De facto, e embora o apelo ao rei não possa ser totalmente desligado do contexto cívico e político, as coordenadas estéticas em que ele se insere projectam-no muito para além da conjuntura, inserindo-o de pleno direito na complexa construção dos valores de um heroísmo que é português e universal, é quinhentista e de todos os tempos. 
Os Lusiadas são um poema de vários princípios: logo na primeira estância a Proposição assinala o começo retórico do discurso; há depois o início da narração da viagem, colocado in medias res (I, 19), segundo o exemplo de Virgílio e o preceito de Horácio; a intriga mitológica começa a ganhar contornos logo na estância seguinte, com o Consílio dos Deuses; chega, por fim, a vez de o Gama abrir a última grande linha de discurso e de acção contando a história de Portugal ao Rei de Melinde (II, 3).

Abstractamente concebido, o Princípio surge assim como tópico de discurso que enforma todo o poema. Determina-o desde logo a índole do género épico, especialmente vocacionado para o desenvolvimento de um projecto de heroísmo centrado na partida e na superaçáo; determina-o ainda a concepção da escrita épica como aventura particularmente dependente do furor divino; e explica-o, por fim, a relação de singular precursividadade que n' Os Lusíadas se estabelece entre o início e a conclusão do discurso. Porém, enquanto na maioria dos poemas épicos, o heroísmo e a glória resultam de um efeito de consumação absoluta, n'Os Lusíadas, o esquema apresenta-se bem menos definido.

É verdade que a Ilha dos Amores configura um final feliz e glorioso da viagem dos nautas portugueses. Em Camóes, porém, a história funciona muitas vezes como um pretexto para o discurso, e as estâncias que se seguem à descrição da apoteose do Amor e do Conhecimento suspendem o encerramento já declarado, instituindo um excurso que se situa já fora do plano da diegese. A circunstância de Os Lusíadas não terminarem com a consagração do herói suscita, só por si, várias questôes que abrangem articuladamente os planos da forma e do conteúdo: refiro-me, concretamente, ao problema da estrutura retórica do poema (fecho canónico /vs/ fecho anti-canónico); ao problema da organicidade do canto camoniano (serão realmente as estâncias finais um desfecho marginal relativamente à matéria épica narrada?); e refiro-me, por fim, ao problema do heroísmo camoniano, uma vez que a inconclusão ou a abertura exortativa do poema se relacionam de perto com a natureza muito particular da realização heróica anunciada desde a primeira estância. Qual o papel do poeta-cavaleiro (o do "braço" e o da "mente") na suspensão desse remate glorioso? Porquê, finalmente, o apelo a uma partida nova?

Apesar de resultarem mais directamente da análise das últimas estâncias do poema, estas questôes requerem todavia a convocação de muitos outros passos da epopeia, de acordo com uma perspectiva de integração co-textual, a única que possibilita, de facto, a aferição dos nexos de sentido de um poema cuja estrutura, como se sabe, assenta muito nas figuras da sobreposição e da contra-dicção.

Se a tópica do princípio apresenta pelo menos três concretizaçôes diferentes e complementares (a Proposição, a Invocação e a Dedicatória), o poema contempla também, curiosamente, outros tantos tipos de fecho: assim, na est. 144, após a consagração da ilha namorada, refere-se o regresso bonançoso dos nautas à sua pátria e ao seu Rei; a estância seguinte assinala uma abrupta inflexão pessoal, no retomar de uma linha de desengano que vem pelo menos desde o final do Canto VI; o remate absoluto do poema culmina com a exortação ao rei D. Sebastião para que rompa nos campos de Ampelusa e protagonize a empresa suprema, digna de ser cantada.

Alinhados desta forma, numa sucessão condensada de 13 estâncias, estes remates parecem contra-dictórios entre si. Porém, e porque a figura da contra-dicção se resolve 
tantas vezes em soluções de síntese ${ }^{1}$, valerá talvez a pena determo-nos um pouco em cada um para vermos até que ponto, também no final, se cumpre o circuito que conduz da dissonância à conjunção.

O primeiro fecho é de todos o mais canónico: depois da demanda e da superação, os preceitos épicos prescrevem a glorificação do herói. O facto de a recompensa se não verificar no termo do regresso (solução que seria mais normal) mas sim ao longo do retorno parece resultar de dois factores de índole diversa: explica-se, em primeiro lugar, por motivos de coerência estética, uma vez que, tendo a viagem decorrido sob a protecção de Vénus, a epifania da ilha dos amores só pode dar-se também no plano mitológico, antes portanto de os nautas serem devolvidos às coordenadas da história real $^{2}$; mas pode também pensarse numa razão de natureza menos imediata: é que, na medida em que o conúbio das ninfas com os nautas significa o nascimento de um herói novo (a "progénie forte e bela", nascida no reino neptunino por disposição expressa da deusa), o incitamento final a D. Sebastiāo, para além do carácter de exortação directa que o contexto histórico esclarece, vai assim ganhar uma efectiva ressonância mítico-lendária que coloca os protagonistas $\mathrm{da}$ aventura portuguesa a meio caminho entre os homens e os deuses ${ }^{3}$.

Cumprido o duplo destino de partida e de cruzada que desde Afonso Henriques impende sobre o "peito ilustre lusitano», vencida a oposição de Baco que, enquanto divindade do Oriente, encarna tanto o temor despeitado pelos feitos que os portugueses hão-de levar a cabo nessas paragens como o desconcerto axiológico (contemplado e verberado por Cupido na sua célebre expedição ao "mundo rebelde") e atingidas as praias de Calecute, numa empresa que coloca simbolicamente em aberto todas as partidas de Ocidente para Oriente, os portugueses, sacralizados pelo esforço, pelo sofrimento e pelo amor, regressam finalmente a Lisboa ao abrigo de qualquer contrariedade. E compreende-se que Camões tenha aqui querido infringir a verdade histórica registada nas crónicas, que dão a viagem de regresso como mais tormentosa do que a da ida ${ }^{4}$,

\footnotetext{
${ }^{1}$ De entre os estudiosos que mais chamaram a atenção para a importância do contraste, da sobreposição e da posterior síntese a nível da construção do poema, é justo destacar Jorge de Sena, "A estrutura d'Os Lusíadas", in A estrutura de Os Lusiadas e outros estudos camonianos e de poesia peninsular do século XVI. Lisboa, Ediçóes 70, 1980, António José Saraiva (“A fábrica d' Os Lusíadas”, in Estudos sobre a arte d'Os Lusíadas. Lisboa, Gradiva, 1992) e Jacinto do Prado Coelho (Camóes e Pessoa, poetas da utopia. Lisboa, Europa/América, 1983).

2 É esta, por exemplo, a explicação aduzida por Jorge de Sena (op. cit., p. 74).

3 Longe de serem entidades passivas sujeitas à acção do Destino, os heróis lusitanos modelam eles próprios o seu caminho. Nesse sentido, podem equiparar-se a alguns reis e guerreiros do ciclo de Tróia e de Tebas, que Hesíodo coloca num patamar intermédio entre a idade do bronze e a do ferro e que, não subindo ao Olimpo nem descendo ao Hades, alcançam a ilha dos Bem-Aventurados, onde recuperam a beatitude original (Cf. Trabalhos e Dias, v. 159 e s.). Para uma análise da questão da idade dos heróis em Hesíodo veja-se Hugo Francisco Bauzà, El imaginario clásico. Edad de oro, utopía y arcadia. Universidad de Santiago de Compostela, 1993, p. 35 e s.

${ }^{4}$ Os registos historiográficos (Barros e Castanheda) dão de facto a viagem de regresso como cheia de calmarias e de doenças. Nela ocorreu, por exemplo, a morte de Paulo da Gama, circunstância que originou inclusivamente o atraso da chegada do capitão da armada a Lisboa, em finais de Agosto de 1499, quase dois

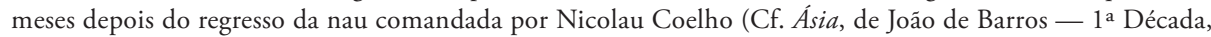
Livro quarto, cap. XI, p. 159 e s.- Edição de António Baião, Coimbra, Imprensa da Universidade, 1932 e História do Descobrimento e Conquista da İndia pelos Portugueses - Livro primeiro, caps XXIV-XXIX, p. 64 e s. - Introdução e revisão de Manuel Lopes de Almeida, Porto Lello \& Irmão, 1979).
} 
uma vez que, a partir do instante da sagração, os nautas devem situar-se já acima de quaisquer contingências.

O seu desembarque na ilha de Vénus equivale, ao mesmo tempo, à nobilitação amorosa pela via da Natureza ${ }^{5}$ e à superaçáo da insegurança humana. A "eterna companhia" que a partir daí fazem às ninfas remete, com efeito, para uma deificação simples (à maneira de Evémero); porém, embora aparentemente fora do tempo, os marinheiros detêm ainda a capacidade para intervir nele, uma vez que continuam vassalos do rei de Portugal, a quem irão entregar "o prémio e a glória". Inscritos num tempo mítico que remonta a Luso e assinalados depois por um trajecto histórico que sob o signo da identidade religiosa vem de Afonso Henriques a D. Manuel, os portugueses reentram depois no plano mitológico, associando-se às ninfas. Estas, por sua vez, por delegação de Vénus, ilustram alegoricamente não só o triunfo do Amor sobre o Despeito (encarnado pela figura de Baco), mas também a vitória da Natureza sobre todas as restriçóes de circunstância ou de essência que tantas vezes a condicionam.

Esta associação entre o humano e o divino, que permite a Camôes desenhar um remate confluente de toda a acção épica considerada nas suas diversas vertentes, não impede, porém, que a história se mantenha em aberto, podendo mesmo dizer-se que daqui resulta uma aparente incongruência. Mesmo imortalizado, o herói não deixa de permanecer humano, o que equivale a dizer que a descrição do domus nympharum não representa, de facto, uma rasura definitiva da história nem uma utopia ${ }^{6}$. E assim, mais do que um expediente estético, a manutenção dos heróis na esfera do humano representa uma possibilidade de reencaminhar o devir temporal até à sublimação, recorrendo, como se verá, à recuperação do tópico da partida, justamente nos últimos versos do poema.

Este cenário de conclusão celebrativa remete, de facto, para a confluência dos principais níveis da diegese, que assim se vêem cerzidos num só desenlace de apoteose. $\mathrm{O}$ significado global destas estâncias, porém, afigura-se bem mais vasto. Entendido apenas como pura consumaçáo em crescendo, o episódio revela-se, de resto, anormalmente longo (210 estâncias), sendo legítimo pensar desde logo que, para além dessa função canónica, de efeitos retroactivos, a Ilha dos Amores, descrita nas suas etapas consecutivas

5 O locus amoenus representado pela ilha centra-se na água e na árvore, enquanto elementos de assimilação, presentes na tradição das paisagens bem-aventuradas.

Favorecidos por Vénus (a mítica mãe da gens Iulia) desde o princípio (I, 33), numa base de filiação declarada, os lusitanos são objecto de um processo de consagração faseada e ascendente que vai do encontro amoroso com as "estranhas ninfas" até à contemplação da máquina do mundo, proporcionada pela titânide Tétis.

${ }^{6}$ Contestando a aplicação do conceito de "utopia" (tal como Thomas Morus o cunhou no princípio do século XVI) ao episódio camoniano da ilha angélica, Martim de Albuquerque sublinha também que " $A$ Ilha dos Amores conta e sublima de forma alegórica a História que Os Lusíadas cantam. Não a repudia. Incita a ela. Como tal não é fuga à realidade, mas exaltação do real desejável e possível.» (Cf. A expressão do poder em Luís de Camóes. Lisboa, Imprensa Nacional/Casa da Moeda, 1988, p. 306).

Por seu turno, Aguiar e Silva, que em 1972 tinha interpretado o episódio num registo utópico ou evasivo ("Função e significado do episódio da Ilha dos Amores na estrutura de Os Lusíadas", in XLVIII Curso de Férias da Faculdade de Letras da Universidade de Coimbra. Ciclo de liçôes comemorativas do IV centenário da publicação de Os Lusíadas. Lisboa, 1972 - republicado em Camóes. Labirintos e fascínios. Lisboa, Cotovia, 1994, pp. 131-143), voltou mais recentemente a defender a pertinência do conceito, embora ressalvando desta vez o seu alcance histórico, aplicável não só ao caso português mas «a todas as partes do mundo" (Cf. "Imaginação e pensamento utópico no episódio da Ilha dos Amores”, in Biblos, LXIV (1988), republicado em Camóes: labirintos e fascínios. pp. 145-153). 
(que integram a preparação do espaço, a sua descrição, o encontro com as ninfas, a perseguição de Leonardo a Efire, o banquete, as profecias da Sirena, a contemplação da máquina do mundo e o regresso bonançoso dos heróis à Pátria) encerra ainda uma dimensão projectiva cujo alcance ultrapassa em muito os limites da história narrada. Penso concretamente na linha de reflexão pessoal que o poeta inaugura logo na primeira estância do poema, ao anunciar a construção heróica de um Reino Novo (antes que esse anúncio seja cometido a Júpiter, a voz aurática que, de forma mais explícita, o retoma na sua segunda profecia - II, 46) ${ }^{7}$. O remate desta linha de discurso só se encontra na estância 145 do Canto X, verdadeiro acme da melancolia camoniana, tomando esta não só na sua acepção pessoal de desengano estético, mas também no sentido de uma degeneração cívica da qual o poeta tem consciência particularmente angustiosa:

“No' mais, Musa, no'mais, que a lira tenho

Destemperada e a voz enrouquecida,

E não do canto, mas de ver que venho

Cantar a gente surda e endurecida.

$\mathrm{O}$ favor com que mais se acende o engenho,

Não no dá a Pátria, não, que está metida

No gosto da cobiça e na rudeza

Dũa austera, apagada e vil tristeza." 8

O contraste entre o épico e o anti-épico (característico de muitas epopeias maneiristas) pode fazer-se equivaler ao preceito retórico do post lucem tenebrae ${ }^{9} \mathrm{Na}$

7 Esta linha discursiva que se faz sentir de forma particular nos finais dos cantos VI, VII, VIII e IX, inclui 84 estâncias integrais (cerca de $8 \%$ do total), de acordo com a contabilidade de Jorge de Sena (Cf. ib., p. 119) e abrange temas muito diversos.

Maria Helena Ribeiro da Cunha procedeu a um levantamento interpretativo dos "epifonemas" d' Os Lusíadas, com incidência especial nos que versam os temas do Amor, do auri sacra fames, do ofício do rei, do ofício de homem e do ofício de poeta. (Cf. "A voz do poeta: epifonemas em Os Lusíadas" in Miscelânea de estudos em honra do Professor Américo Costa Ramalho. Lisboa, INIC, 1992, pp. 503-530).

Para além da obra já clássica de Bowra (From Virgil to Milton: a study of the epic. London, Macmillan, 1945), a importância da figura do poeta na épica foi ainda objecto de um estudo de grande alcance e solidez, da autoria de Robert M. Durling. Partindo de dois poetas tardo-medievais (Chaucer e Petrarca), o estudioso em questấo detém-se depois em 4 autores renascentistas (Boiardo, Ariosto, Tasso e Spenser), para assinalar a presença crescente da voz do poeta que, em Ariosto e em Tasso, chega a assumir o papel de um autêntico demiurgo, náo só seleccionando e controlando os eventos mas também comentando-os e caracterizando os intervenientes num registo abertamente moral e axiológico. (Cf. The figure of the poet in renaissance epic. Cambridge and Massachussetts, Harvard University Press, 1965, em especial as p. 128 e s.).

${ }^{8}$ As citações do texto camoniano são feitas a partir da ediçấo de Álvaro Júlio da Costa Pimpão (Lisboa, Instituto Camóes, 1992).

9 Em termos gerais, este topos parece inspirar-se essencialmente na Farsália de Lucano, texto que, aliás, se revela, a muitos outros títulos, uma fonte camoniana privilegiada. Sobre o assunto veja-se Daniel Madélénat, L'épopée. Paris, PUF, 1986, p. 44 e pp. 200-201.

Ainda a propósito desta estância, Faria e Sousa enumera fontes muito variadas que, no entanto, abrangem sintomaticamente mais a poesia lírica (Marcial, Terêncio, Virgílio - na égloga $10^{\mathrm{a}}$-, e Guarino Guarini) do que a poesia épica. (Cf. Lusiadas de Luis de Camóes comentadas por Faria e Sousa. Lisboa, Imprensa Nacional/Casa da Moeda, 1972, pp. 582-86). 
disforia que a assinala (e que se sobrepóe pela abrangência e pela explicitude a qualquer outra estância do poema), esta estância ganha, porém, neste contexto, um sentido invulgar de contraste e de transição, parecendo, por um lado, entrar em colisão absoluta com o cenário de triunfante serenidade anteriormente registado e prenunciando ainda, por outro lado, uma qualquer solução de síntese.

Para além do tom, o contraste opera-se também a nível enunciativo. Depois do pretérito perfeito e da terceira pessoa funcionalmente demarcada, que predominam nas estâncias anteriores, emergem, de repente, o presente do indicativo e uma primeira pessoa alheia à instância narrativa anterior. $\mathrm{O}$ encerramento da narração mítica ocorre quando a história faz de novo valer os seus direitos, irrompendo numa implosão do heroísmo antes celebrado: os efeitos de dissonância são os mesmos que assinalam tantos passos anteriores; mas reforçados, desta vez, pela circunstância decisiva de nos encontrarmos no final do poema, podendo por isso a sobreposição do presente histórico ao passado mítico ser interpretada como uma efectiva consumação. Para que assim não seja é necessário que a narrativa náo termine com o registo do presente, disforicamente caracterizado pela ausência de matéria épica e pelo desacompanhamento das Musas. E assim, depois de na Invocação se ter aberto a dialéctica entre a História e o Mito e de, no fim desta longa aventura da narraçáo, se ter dado como assente que a primeira vertente corroeu a segunda, pode ainda assistir-se nas últimas onze estâncias ao seu resgate derradeiro.

Concluída a evocaçáo do passado, sempre centrada na Guerra e no Amor (valores que n' Os Lusiadas se implicam causalmente) e negada a hipótese de euforia no presente, resta a construçáo projectiva de um futuro. Nesse sentido, o poeta apela a uma partida nova, recuperando o tom épico já depois de o ter denegado. O apelo a D. Sebastião para que retome a expansão no Norte de África, até pelo próprio desfecho da batalha de Alcácer Quibir, tem sido sobretudo lido à luz das coordenadas históricas que o justificam. A verdade, porém, é que no momento da enunciação, a partida por que clama o poeta parece ter um sentido mais amplo e mais vago, inscrevendo-se antes na linha subordinante de todo o epos camoniano: reunir o mito e a história no mesmo plano de eucronia que subordina toda a história de Portugal, tal como ela é narrada desde Afonso Henriques até aos feitos da Índia ${ }^{10}$.

Deste modo, enquanto do primeiro momento (o da Ilha dos Amores) para o segundo (o da crítica deceptiva) se verifica uma alteração marcante de tom e de instância enunciativa, do segundo para o terceiro momento (o da exortação a D. Sebastião), a primeira pessoa mantém-se. Conclui-se assim que se o narrador que evoca a Ilha dos Amores até à est. 144 se situa no nível extradiegético, de onde exerce a sua acção

${ }^{10}$ De facto, fundada sob a égide do mito áureo do Cristo aparecido em Ourique, a naçấo portuguesa encontrava-se agora em estado de deperecimento, esquecido o mito sacralizante da fundação e o telos cruzadístico que daí resultou.

Embora o mito de Ourique possa rastrear-se pelo menos desde a Segunda Crónica Breve de Santa Cruz de Coimbra (1451), parece não haver muitas dúvidas sobre a possibilidade de Camóes ter recolhido o motivo directamente na Crónica de D. Afonso Henriques, de Duarte Galvão (1505).

Sobre o mito das origens e o seu tratamento historiográfico e literário veja-se a síntese de Ana Isabel Buescu "Vínculos da memória: Ourique e a fundação do Reino", in Portugal: mitos revisitados. Coordenação de Yvette Centeno. Lisboa, Ediçôes Salamandra, 1993, pp. 9-50. 
reguladora sobre a diegese da viagem e da mitologia, o enunciador que certifica a «apagada e vil tristeza» é literalmente o mesmo que apela à sua superaçáo através de uma nova partida e de um novo princípio, retomando as linhas de sentido já abertas na Dedicatória ao rei menino ${ }^{11}$. E se pode dizer que o primeiro narrador é um inventor de "fábulas sonhadas", o segundo é o vate que se situa no plano da realidade, existindo por si mesmo, qual voz sem narração, guerreiro sem epopeia e poeta sem poesia.

Os três momentos de fecho do poema articulam-se portanto numa base de coerência sintáctica e semântica: depois do remate canónico da diegese épica (est.144), segue-se o envoi que incide sobre o plano anti-épico do presente; e temos, por fim, um fecho resgatante, na medida em que intenta superar o presente e recuperar os modelos do passado, projectando-os num sonho de futuro sem limites.

E é nessa tentativa de síntese entre os planos do real e do ideal que ganha importância a figura do Rei Desejado. Poderia pensar-se que, ao dirigir-se-lhe expressamente na Dedicatória e na exortação final, o poeta nomeia um herói virtual, ao mesmo tempo que desmente a possibilidade de o Gama ou algum dos "baróes ilustres" referidos ao longo da epopeia poderem vir a ser entendidos num plano de completa heroicidade. Por outras palavras, poderá pensar-se que o poeta enfatiza o futuro não só para obliterar o presente mas também para desvalorizar o passado.

Os feitos narrados, como o próprio canto épico, são endossados ao rei, quer como seu beneficiário directo, quer como seu continuador. Situado a este nível, D. Sebastião é não apenas o depositário do passado mas também a esperança concentrada da sua sublimação. Pelas suas potencialidades de resgate em relação à realidade portuguesa, a figura do rei integra-se no contexto de uma expectação messianista, do mesmo modo que o sentido camoniano da missáo lusíada se enquadra num lastro providencialista em que o tempo da história (concretamente balizado pela pressão dos turcos sobre a Europa e pelo direito de conquista contra os mouros ${ }^{12}$ ) se amplifica em ordem a uma espécie de tempo hiero-histórico de alcance universal e ecuménico ${ }^{13}$.

${ }^{11}$ Comentando justamente as intervençôes do poeta em final de canto, Jorge de Sena refere-se à ligação entre a Dedicatória e as últimas estâncias do poema desta forma bem sugestiva: "É óbvio que a [estância] que conclui o canto $X$ tem características especiais de rounding-up do poema, em contrapartida da introdução do canto I.» (Cf. ib., p. 124).

12 Em 1570, os turcos tinham-se apoderado da ilha de Chipre. Organizada logo a seguir, a "Santa Liga”, reuniu, à volta de Filipe II e do papa Pio V, Veneza, Génova, Sabóia e os cavaleiros de Malta. E foram essas forças conjugadas que, sob o comando de D. João de Áustria, derrotaram os turcos na batalha de Lepanto, sustendo o seu avanço no Mediterrâneo.

13 As trovas de Gonçalo Anes Bandarra (escritas antes de 1541) falam já, em abstracto, de um rei que traria a paz e a justiça ao mundo, vindo essa ideia a encontrar um justificado acolhimento depois da fatal jornada africana de D. Sebastiăo.

Retomando uma pista de Sampaio Bruno, António Franco Alexandre situa a génese da ideia do Encoberto no reino de Valência, aquando da tentativa de confirmação de Carlos, neto de Maximiliano, como rei daquele reino, e do aparecimento de uma figura, supostamente filha do príncipe João, herdeiro jurado dos Reis Católicos, falecido poucos meses após o seu casamento com Margarida de Áustria, que ficou grávida (Vida de D. Sebastião, Rei de Portugal. Lisboa, Europa/América, 1993, p. 191 e s.).

Para uma análise das repercussôes do mito do Encoberto na mentalidade e na cultura do século XVII, veja-se ainda o excelente estudo de Diogo Ramada Curto "O Bastiāo, Bastiāo", in Portugal: mitos revisitados, pp. 139-176. 
Num plano mais imediato e pessoal, D. Sebastião é o herói que comanda ( «enhor de vassalos excelentes»), cujo exemplo de justiça suscita, por si só, os ímpetos de perseverança e de coragem necessários à fábula épica ${ }^{14}$. Nessa perspectiva, a ligação das estâncias finais à Dedicatória recoloca e potencia o tópico da idade dourada, tradicionalmente anunciada pelo nascimento de um menino que suprime o desconcerto anterior (neikos) e reinstaura a philia ${ }_{2}$ estado que equivale, na prática, à verdadeira pax christiana, definida por Júpiter na já citada estância 46 do Canto II, quando depois de profetizar os triunfos lusitanos contra os infiéis, sintetiza desta forma a etapa final do Reino Novo ${ }^{15}$ :

“

E por eles, de tudo enfim senhores,

Serão dadas na Terra leis milhores."

Desta forma, e na medida em que o futuro se junta ao passado, o tempo acaba por surgir na epopeia camoniana como uma coordenada em aberto e D. Sebastiáo como o intérprete pontual de um devir em que o "peito ilustre lusitano» figura como protagonista constante e indelimitado. Os conselhos de benignidade e heroísmo dirigidos ao monarca podem ainda ser lidos como uma censura indirecta aos desmandos de alguns antecessores que não souberam assumir-se no quadro da excelência, cumprindo o quadro ideal de relaçóes com os súbditos. Se tivermos em conta o modelo de intercomunicação ontológica que permite aos deuses «descer ao vil terreno / E os humanos subir ao Céu sereno", concluiremos que a síntese entre o herói e o poeta, apesar de possível, não chegou a verificar-se. Ora, enquanto destinatário privilegiado do canto e protagonista de uma nova empresa "digna de ser cantada", D. Sebastião surge como o herói auroral e como projecção do herói-sábio que é o poeta ${ }^{16}$.

Depois de, durante oito estâncias (146-153), se ter situado num registo abstracto e colectivo, o poeta reassume o discurso de primeira pessoa nas três últimas estâncias justamente para se destacar dos vassalos e apresentar ao Rei em termos pessoais a quotaparte de heroísmo que lhe cabe: o "braço" e a "mente" 17 . A reunião dos dois elementos na pessoa do poeta configura bem a sua auto-estima heróica; mas, mais do que isso, a vanglória e o oferecimento exortativo com que a epopeia se conclui traduz a inadequação entre o canto e a matéria que o inspira. Afinal, depois de, na Dedicatória, ter certificado

\footnotetext{
${ }^{14}$ A associação entre as virtudes de chefia do Rei e a excelência dos vassalos é recorrentemente expressa n' Os Lusíadas como requisito de pleno heroísmo, tanto num registo afirmativo (veja-se, por exemplo, a exortação de D. Nuno Álvares Pereira aos portugueses (IV, 14-19), como num registo negativo, ilustrado, por exemplo com a figura de D. Fernando, o «fraco Rei que faz fraca a forte gente» (III, 138-143).

${ }^{15}$ Para além de uma vasta representação na literatura grega e latina, a ideia da sucessão cíclica das idades encontra-se ainda largamente ilustrada em múltiplos textos da Antiguidade oriental (Cf. Hugo Francisco Bauzá, op. cit., p. 19-55).

16 Sobre a necessária complementaridade entre o herói sábio e o herói auroral, vejam-se Bowra, Heroic poetry. London, Macmillan, 1952, p. 9 e Madélénat, op. cit., p. 55.

${ }^{17}$ Rejeitando a interpretação da atitude do poeta num registo de humildade, Hélder de Macedo lê estas estâncias como um sinal de emulação da figura rude do velho Sileno, o deus da eloquência e da profecia (Cf. “o Braço e a mente: o poeta como herói n' Os Lusiadas”, in Arquivos do Centro Cultural Português, vol. XV, 1980, pp. 61-72).
} 
ao Rei que a fama das vitórias dos guerreiros da Antiguidade se encontra já ultrapassada pela glória do "peito ilustre lusitano", o poeta termina com dois versos que fazem depender da «digna empresa de Marrocos» a equiparação de D. Sebastião a Aquiles e a Alexandre:

"Ou fazendo que, mais que a de Medusa,

A vista vossa tema o monte Atlante,

Ou rompendo nos campos de Ampelusa

Os muros de Marrocos e Trudante,

A minha já estimada e leda Musa

Fico que em todo o mundo de vós conte,

De sorte que Alexandro em vós se veja

Sem à dita de Aquiles ter enveja."

$(\mathrm{X}, 156)$

Mesmo os feitos gloriosos dos «altos varôes que hão de vir ao mundo», postos na boca da «angélica Sirena» ${ }^{18}$, (em claro resultado de um processo de decalque da sereia do Canto VII da Eneida) abrangem acontecimentos já inscritos na factualidade histórica. Considerando que entre o princípio e o termo da epopeia decorre toda a narraçáo épica, é legítimo pensar que, depois de passar pela trama da História de Portugal, considerada na sua dimensão europeia e, depois, na sua orientação ultramarina, o poeta vê-se obrigado a suspender a consagração do herói, transferindo-a para um futuro iminente só acessível através da profecia.

Mais do que símile de abertura do poema, a Dedicatória surge, pois, como tópico de alcance extradiegético, religando num registo simultâneo de evocação e de advento a fundação da nacionalidade e o seu cumprimento cabal, numa base de redenção que supóe o fim de todas as quedas e de todos os desconcertos. Numa perspectiva de protagonismo régio, esse cumprimento inicia-se sob a égide da cruzada, com a figura de D. Afonso Henriques, seguindo depois um trajecto que conduz ao neto de D. João III, «...tenro e novo ramo florescente / De uma árvore de Cristo mais amada», a quem está providencialmente cometida a responsabilidade de retomar a linha de Ourique.

Uma vez que todos os protagonistas se afastam do ideal compósito que é reiteradamente estabelecido com base em qualidades de coragem física, de perseverança, de inteligência e de valia moral e intelectual, poderia concluir-se então que o heroísmo é transferido do plano da diegese para o plano da enunciação autoral ${ }^{19}$. A leitura d' $O s$

18 Já no decurso do consílio dos deuses marinhos, Proteu - o deus da profecia - se dispusera a dizer "o que sentia", quando foi interrompido por Tétis. Reveladas por Júpiter em sonhos a Proteu, só agora, depois de consumada a aventura da viagem, estas sấo colocadas na boca de uma ninfa, que as reteve na memória.

${ }^{19}$ Antes de Hélder de Macedo, que, em meu entender, leva o heroísmo do Camóes-poeta a níveis de algum exagero, já Jorge de Sena tinha interpretado o final d'Os Lusíadas no mesmo sentido, desvalorizando (com excessiva radicalidade) a importância da história e as implicações do próprio jogo enunciativo: «E o terminar uma epopeia com promessas de outra não é das menores demonstrações de quanto o poeta é central, do mesmo passo que é uma sublime ironia: as epopeias não se prometem, fazem-se do que já é matéria delas. A menos que, como em todo o Camóes sucede, nada seja autorizado a existir senáo nele, com ele, e por ele." (Cf. "Aspectos do pensamento de Camôes através da estrutura linguística de Os Lusíadas", in I Reunião Internacional de Camonistas. Lisboa, 1973, p. 51). 
Lusíadas como "epopeia da poesia" favorece, de facto, a compreensão de uma das suas mais importantes linhas de especificidade, traduzida pela supremacia órfica do canto em relação à matéria cantada e da voz do autor relativamente às vozes das personagens e à própria narrativa de acontecimentos. Essa marca de singularidade não pode, porém, dissociar-se da questionação ética e estética dos modelos antigos e modernos, dos quais o poeta português parte para uma das mais importantes reconversôes do cânone épico ocidental, tanto em termos dos valores que balizam a acção, como em termos do próprio estatuto do canto e das suas capacidades de sublimação.

Para reavaliar esta questão dentro do quadro de análise em que agora me situo, é necessário reconhecer que a Dedicatória e o termo do poema camoniano se articulam em termos de voz e de eco que se prolonga até ao silêncio de uma expectativa que é simultaneamente histórica e estética. E o siginificado global do poema náo pode, de facto, decidir-se sem se ter em consideração a dupla qualidade desta expectativa.

Mais do que a oposição entre o épico e o anti-épico, é a tensão dialéctica entre a História e o Mito que funda o discurso camoniano, percorrendo-o de forma estruturante e obsessiva. Com efeito, quando se esperava que a apoteose e a recompensa da ilha namorada viessem a constituir a triunfo supremo e irreversível do Mito, eis que a indecisão não está resolvida e o poema termina afinal da mesma forma como tinha começado: com a miragem de que a História se transfigure em Mito.

A circunstância de Os Lusíadas terminarem com a exortação a uma aventura africana numa altura em que a prudência política desaconselhava tais veleidades, tem valido a Camôes condenaçóes mais ou menos severas ${ }^{20}$. Basta, porém, deslocar a interpretação do fenómeno, destacando-o do contexto histórico que conduz a Alcácer-Quibir e integrando-o nas linhas gerais do pensamento e da arte de Camóes, para que a sua apreciação passe a fazer-se a uma outra luz.

Assim, no que respeita ao primeiro nível, basta lembrar que no episódio do Velho do Restelo, a África surge náo tanto como um sonho imperial, mas como uma possibilidade de redenção moral da $\mathrm{Nação}^{21}$. E parece ser sobretudo nesse sentido que o vassalo se manifesta agora investido de faculdades físicas e mentais que coloca à

20 Ocupando-se do problema do heroísmo camoniano no contexto das relaçóes entre a história e o mito, Luís de Oliveira e Silva, subestimando justamente a perspectiva estética, resvala para uma posição de crítica (e de censura) directa ao poeta (que faz lembrar a atitude crítica de alguns árcades), apontando-lhe inclusivamente o vitium do patriotismo e a consequente "carência de distanciamento crítico", para concluir reprovadoramente: "O poema épico, quando tem por objecto matéria puramente histórica não se pode dar ao luxo de formular um juizo definitivo [...] Porque o futuro, que num poema de carácter histórico não deve ser considerado extradiegético, pode, eventualmente, desarticular a hipérbole ascendente e, trágica e ironicamente, revelar a fragilidade da ostentação pretensiosa" (Cf. "Identidade e identificação interactiva n' Os Lusiadas", in Dedalus, 5 (1995), pp. 228-29).

${ }^{21}$ Independentemente das evidentes marcas de retórica humanista que existem no discurso do Velho (e que o fazem antepor os valores da renúncia aos ímpetos da aventura), parece claro no seu discurso que África oferece aos portugueses uma oportunidade segura de retomar a senda cruzadística que legitima a nação lusa desde a sua fundação.

Nesse sentido, e contrariamente ao que defende Luís de Oliveira e Silva, tendo para crer que, mais do que um puro desmoronamento da Weltanschauung heróica ("A crítica da virtude heróica no Velho do Restelo", in Mitos revisitados, pp. 69-97), o episódio constitui uma etapa de um processo de reconversão moral e cristâ, que se estende, aliás, até às estâncias finais do poema. 
disposição de um soberano promissoramente justo e liderante. Já em termos estéticos o apelo a uma nova partida significa sobretudo o incumprimento do programa épico anunciado desde a primeira estância e a esperança de o poder completar.

Mais do que um simples excurso adulatório, o apelo a D. Sebastiāo e a promessa de "um nunca ouvido canto» têm, assim, a dupla função de atenuar o pessimismo da estância 145, ao mesmo tempo que representam a possibilidade de recuperar o projecto, entretanto desbotado, da construção de um "Reino Novo". O programa inicial reaparece, de facto, mas transferido agora para um futuro onde o Mito e a História possam enfim confluir. Só assim se explica que, embora enquadrada pelo envolvimento dual da Fé e do Império em que a acção dos lusitanos se inscreve, essa confluência acabe por ter efeitos de catarse colectiva. E porque só no tempo a esperança é possível, Camôes converte o passado fechado da epopeia em promessa de futuro, recorrendo afinal ao expediente comum dos que não se conformam com a realidade e a trocam pela magia do sonho e pelo sortilégio da poesia que lhe dá corpo.

Para além do significado político de circunstância, o encerramento do poema com uma exortação e uma profecia constituem assim sinais de uma verdadeira teofania poética, que não parece arriscado relacionar com o forte lastro neoplatonista que inspira a criação camoniana, muito para além da simples imitação de topoi. Concebida na sua globalidade, a epopeia camoniana cumpre, de facto, as quatro etapas do furor divino, tal como Marsilio Ficino (a figura mais marcante do neoplatonismo renascentista) as define $^{22}$ : o furor amatório constitui a base de toda a acção épica, compreendendo tanto a intriga mitológica (que evolui com base no conflito entre Vénus e Baco), como a história de Portugal (toda centrada em situaçóes afectivizadas), a viagem do Gama e a própria aventura da poesia, uma e outra ditadas pelo supremo amor da Pátria; o furor religioso é um dos elementos fundacionais de toda a ideologia camoniana e, embora a sua presença se faça sentir ao longo de todo o discurso épico, encontra uma tradução muito particular em três momentos marcantes, em que o heroísmo é associado aos valores da cruzada cristã: o episódio do Velho do Restelo, o início do Canto VII e as estâncias que o poeta dirige a D. Sebastião na Dedicatória e no remate final da epopeia; o furor poético, por sua vez, consubstancia-se desde o início na invocação da "fúria grande e sonorosa», e na presença assídua das Tágides que certificam a inspiração possessa e demiúrgica do Canto, apesar dos silêncios ingratos que se lhe seguem.

Temos, por fim, o furor profético. E se é verdade que a profecia é também colocada na boca de personagens alegóricas ou mitológicas como Júpiter (II, 44-46), os rios Indo e Ganges (IV, 68-74), ou a ninfa dos Cantos IX e X, abrangendo acontecimentos intradiegéticos, num quadro estruturado de coesão preditiva muito próprio da narrativa épica, ela só ganha um alcance verdadeiramente teúrgico quando é protagonizada pelo narrador do primeiro nível. Situado abertamente no presente da história, a voz autoral está em condiçôes privilegiadas para assumir a sua crítica e apontar caminhos de redenção. Por isso, só ele tem o dom de decifrar o futuro no quadro de um programa

22 Sobre a teoria do furor, tal como ela se apresenta em Platão e nos seus comentadores renascentistas, veja-se a excelente Introdução de Pedro Azara a Marsilio Ficino, Sobre el furor divino y otros textos. Barcelona, Anthropos, 1993 (edição bilingue).

Veja-se muito em particular a carta de Ficino a Pedro Divino (pp. 54-63). 
cívico e estético em que se sente simultaneamente implicado como poeta e como vassalo do Rei de Portugal.

Concluindo desta forma a sua epopeia, Camôes revela-se fiel ao sentido épico da história da Pátria. Se a «apagada e vil tristeza» assinala o fim de um ciclo marcado pela "vã cobiça» e pela "vaidade», a exortação africana surge como o começo de uma fase nova, decantada e restituída à pureza dos valores da Fé e do Império ${ }^{23}$.

Para além do "braço" do cavaleiro, essa nova era deverá porém ser sacramentada com a palavra épica. E nesse sentido, mais do que um simples complemento do esforço individual, a mente do poeta surge como via de sublimação de uma guerra protagonizada por um herói colectivo: o "...peito ilustre lusitano / A quem Neptuno e Marte obedeceram». Colocados tantas vezes ao longo do poema num plano de divergência que parecia insanável, o Canto e a matéria cantada confluem, por fim, nesse horizonte virtual, aberto pela pulsão da profecia. Só nessa medida é possível rasurar as sombras do tempo presente em nome de um futuro de luz, "ad infinitum". E nesse registo de esperança projectada na eternidade o Mito e a História já não se distinguem.

\footnotetext{
${ }^{23}$ Mais do que pelo enaltecimento canónico das grandezas pátrias, Os Lusíadas inserem-se assim na linha do messianismo português (em que se integra o quinto império) pelo capital de esperança que projectam num novo porvir, que tanto pode tomar a forma imediata e visível das vastas planícies africanas como pode transformar-se no advento escatológico sonhado por Vieira.

Apesar de dispormos já de valiosos contributos para o esclarecimento desta questão, estará talvez ainda por fazer o levantamento sistemático da recepção messianista d' Os Lusíadas, desde o Barroco até aos nossos dias, na Literatura, na Cultura e na Mentalidade portuguesas.
} 